\title{
Questionnaire vs. Social Media Analysis - Case Study of Organic Food
}

Ladislav Pilařํㅜ, Lucie Kvasničková Stanislavská1, George Gresham², Jana Poláková1, Stanislav Rojík ${ }^{1}$, Rosen Petkov ${ }^{3}$

${ }^{1}$ Faculty of Economics and Management, Czech University of Life Sciences Prague, Czech Republic

2 Davis College of Business, Jacksonville University, USA

${ }^{3}$ Department of Electronics and Informatics, Technical University of Sofia, Bulgaria

\begin{abstract}
The amount of European farm acreage devoted to organic foods has been increasing each year over the past three decades, as farmers strive to meet consumer demand for these products. To understand what factors drive this demand, researchers have focused on the end customers' perception of organic food and their motivations to purchase it. The standard research methods are questionnaires and literature review; however, these tend to be expensive, time consuming, or involve work with secondary data. This paper compares 14 studies carried out using standard research methods with the results of a social network analysis based on 344,231 posts by 73,380 Instagram users. The result of the comparison shows that in the case of organic food, the characteristic of "healthy" is the most important one to customers, both based on questionnaire surveys and the social network analysis. Moreover, based on these two analyses, 4 key areas can be identified as factors that are important to customers buying organic food: (1) health consciousness, (2) ecological motives, (3) tasty and (4) hedonism. As the results indicate, social network analysis can be considered a method with a high potential for gaining a greater insight into customers' perceptions.
\end{abstract}

\section{Keywords}

Organic food, questionnaire, social media analysis, hashtag, healthy.

Pilař, L., Kvasničková Stanislavská, K., Gresham, G., Poláková, J., Rojík, S. and Petkov, R. (2018) "Questionnaire vs. Social Media Analysis - Case Study of Organic Food", AGRIS on-line Papers in Economics and Informatics, Vol. 10, No. 3, pp. 93-101. ISSN 1804-1930. DOI 10.7160/aol.2018.1003308.

\section{Introduction}

In the past three decades, organic farming and acreage devoted to organic foods have been growing in Europe every year. Currently, organic food is grown on 50.9 million hectares globally, i.e. on $1 \%$ of global agricultural land and $6.2 \%$ of agricultural land in the EU (Willer and Lernoud, 2016). The increase in ecological farming is related to consumers' interest in topics such as environmental protection, production of highquality, safe food, and creation of good living conditions for animals (Brožová and Beranová, 2017). Consumers see ecological farming contributing to the production of environmentallyfriendly, healthy, nutritious and high-quality food, thanks to the production processes and practical procedures (Vaněk et al., 2013; Pilař et al., 2018). These include using a limited amount of synthetic pesticides and fertilizers, only feeding animals with low amounts of concentrated feed (Popa et al., 2018) and producing food with a greater content of vitamins and minerals compared to conventional food products (Worthington, 2001).

The changes in consumers' behaviour need to be identified and analysed. That's why in the past years, several studies have been carried out on customers' attitude to organic food and their motivations to buy it. The results of the studies have shown that organic food is very often connected with the characteristics of "more expensive" (Hasimuu et al., 2017; Bryla, 2016), "tastier" (Bryla, 2016; Lea and Worsley, 2007), and primarily "healthier" (Asif et al., 2018; Hansen et al., 2018; Hasimu et al., 2017; etc). However, the actual effect of organic food on human health hasn't been sufficiently proved, as indicated by the results of studies carried out by Popa et al., 2018; Brennan et al., 2003; Huber et al., 2011.

The above mentioned studies examined the customers' perception of organic food using questionnaire surveys and interviews. The most frequently used data collection methods in organic 
food research involve online surveys or structured questionnaires. In spite of their popularity, questionnaire surveys have certain disadvantages. Questionnaire design requires a wide range of knowledge and training, questionnaires with many open-ended questions can generate large amounts of data, and it takes significant effort to analyse and even more time to interpret them. However, the greatest disadvantage is the low response rate and time consuming nature of the research (Wilson, 2013). In the studies concerned, the sample of respondents ranged between 100 and 1,000 people. In contrast, modern research methods, such as social network analysis, allow for collecting data from a sample of several hundred thousands of respondents.

\section{Social media as a data opportunity to research}

Currently, there are more than 2.5 billion social network users and it is expected that by 2021 , there will be 3 billion of them (Statista, 2017). Social network users are no longer mere content consumers; they create their content themselves (Malthouse et al., 2013). The fastest growing social network is Instagram with 800 million active users (Aslam, 2018). Every day, Instagram users upload more than 95 million pictures and have 4.2 billion interactions using "like". This activity creates a huge potential for research organisations' analyses of this data.

\section{Aim of the present study}

The aim of the study is to identify the differences and potential added value of social media analysis based on social network analysis as a method to evaluate knowledge collected using questionnaire surveys in the field of customers' perception of organic food.

In this article, we review and discuss the perception of organic food by end customers and their motivations to buy organic food.

We describe the perception of organic food on social networks based on 344,213 posts of 73,380 unique users on Instagram worldwide by identifying the most commonly used hashtags on social networks related to the term organic food by means of a social network analysis.

The results of the social network analysis are compared to the results of 14 studies conducted using standard research methods.

\section{Materials and methods}

In this paper, two areas of research methods were used: social network analysis and literature review.
The aim of the social network analysis is to understand the structure of the network and identify the significance of individual nodes (or hashtags in this study) by defining their position and significance in the network (Oliveira and Gama, 2012). The input data for the analysis were collected by Netlytic (Gruzd, 2016) between 2017-07-30 and 2018-03-09 by identifying the hashtag \#organicfood in the posts. Individual data is stored in data sets containing 100,000 posts. In total, the analysis involved 340,358 posts from 73,380 unique users. Considering the great amount of input data, with individual data packages containing from $1,719,329$ to $1,912,679$ unique words, the data to be further processed was filtered twice. At the first stage, hashtags were extracted starting with \#. Using hashtags, Instagram users communicate the most important characteristics they want to relate together with the picture (Pilař et al., 2017). The second stage of filtering eliminated hashtags repeated in the data set less than 100 times. The filtering narrowed down the data set to 6,247 most frequently used hashtags. This data were then inserted into Gephi 0.9.2, creating a network containing 6,247 nodes (hashtags) connected by $1,992,499$ edges. To identify the significance of the individual hashtags, the following statistical methods were used:

\section{Degree centrality}

This centrality measures the activity that the node shows in the network. High-value nodes have "centers" in a given network. The degree $k_{i}$ of a node $i$ is defined as the number of its neighbors, that is, the number of links incident to node $\mathrm{i}$, where $\mathrm{a}_{\mathrm{ij}}$ the elements of the adjacency A matrix $\Pi_{i}$ and the neighborhood of node $\mathrm{i}$ (Antoniou and Tsompa, 2008):

$$
\mathrm{k}_{\mathrm{i}}=\sum_{\mathrm{j} \in \Pi(\mathrm{i})} \mathrm{a}_{\mathrm{ij}}
$$

\section{Eigenvector centrality}

Eigenvector centrality is a score expressing the "importance" of a node in the network. The score of this parameter is based on the assumption that the connection with nodes of higher importance increases the importance of this node more than the connection with nodes of less importance. Eigenvector centrality is a relative score recursively defined as a function of the number and strength of connections to its neighbours and as well as those neighbours' centralities (Ilyas and Radha, 2011). $X_{i}$ is score where A means the neighbourhood matrix. After editing, $x$ meets the equation $A_{x}=\kappa_{1 x}$, 
where $\kappa_{1}$ is its largest own number (that means, $\kappa$ is the number for which applies that $A_{x}=\kappa_{x}$, where $\mathrm{x}$ is the vector itself) and $\lambda$ is the maximum eigenvalue of the matrix $A_{2}$.

$$
X_{i}=\frac{1}{\lambda} \sum A_{x j} X_{j}
$$

The review process followed the procedures described in Systematic Reviews in the Social Sciences: A Practical Guide (Petticrew and Roberts, 2008). Research was looked up in the Science Direct and Google Scholar databases. To look up the relevant research, the following key words were used: "consumers' attitude towards organic food", "purchase intention for organic food" and "willingness to pay for the organic products". Only the research using questionnaire surveys was included in the review.

\section{Results and discussion}

Based on our degree centrality analysis, it is possible to identify the 5 most significant hashtags in the network in terms of their connection to other hashtags. This value allows for identifying the 5 most significant hashtags: \#healthyfood, \#vegan, \#healthy, \#eatclean, \#vegetarian, see Table 1.

Degree distribution corresponds with the long tail characteristic. There are only 5 hashtags with a degree higher than 5,200. On the other hand, most hashtags fall into the category with a degree between 0 and 1299, which is a strong indication of the standard behaviour in social networks regarding hashtag usage (Kordumova et al., 2016) see Table 1 and Figure 1.

Based on our eigenvector centrality analysis, it is possible to identify the 5 most significant

\begin{tabular}{|l|c|c|c|c|c|}
\hline Hashtags & \#healthyfood & \#vegan & \#healthy & \#eatclean & \#vegetarian \\
\hline Degree & 5537 & 5483 & 5435 & 5110 & 4901 \\
\hline Degree range & $\mathbf{5 2 0 0 - 6 4 9 9}$ & $\mathbf{3 9 0 0 - 5 1 9 9}$ & $\mathbf{2 6 0 0 - 3 8 9 9}$ & $\mathbf{1 3 0 0 - 2 5 9 9}$ & $\mathbf{0 - 1 2 9 9}$ \\
\hline No. of hashtags & 5 & 43 & 134 & 566 & 5499 \\
\hline Percentage & $0.08 \%$ & $0.69 \%$ & $2.15 \%$ & $9.06 \%$ & $88.03 \%$ \\
\hline Eigenvector Centrality & 0.981427 & 0.980745 & 0.978377 & 0.959511 & 0.950584 \\
\hline Eigenvector Centrality Range & $\mathbf{0 . 8}-\mathbf{1 . 0}$ & $\mathbf{0 . 6 - 0 . 7 9}$ & $\mathbf{0 . 4 - 0 . 5 9}$ & $\mathbf{0 . 2 - 0 . 3 9}$ & $\mathbf{0 - 0 . 1 9}$ \\
\hline No. of hasthtags & 73 & 194 & 474 & 1.7 & 3.806 \\
\hline Percentage & $1.17 \%$ & $3.11 \%$ & $7.59 \%$ & $27.21 \%$ & $60.93 \%$ \\
\hline
\end{tabular}

Note: The highest degree: \#organic food: 6.245

Source: own processing

Table 1: Degree Centrality and Eigenvector Centrality of hashtags at social network based on the \#organicfood hashtag.

\section{Degree Distribution}

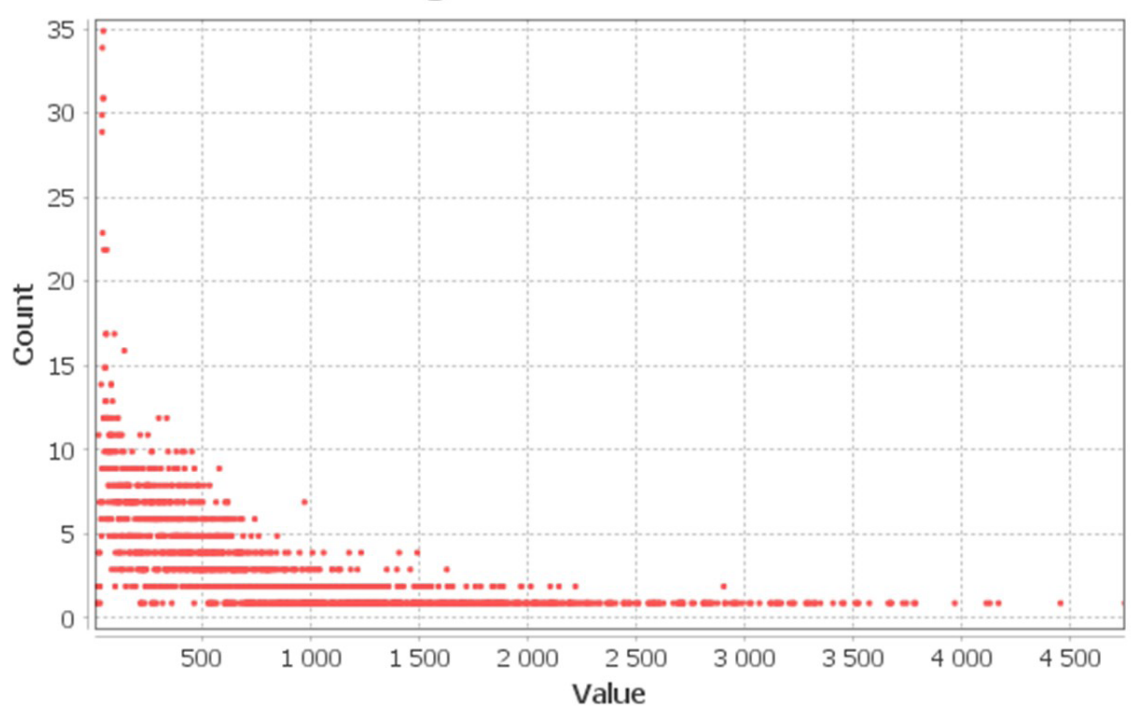

Source: own processing

Figure 1: Degree centrality distribution of hashtags connected to hashtag \#organicfood. 
hashtags in the network in terms of their connection to other hashtags. This value allows for identifying the 5 most significant hashtags: \#healthyfood, \#vegan, \#healthy, \#eatclean, \#vegetarian, see Table 1.

Degree distribution corresponds to the long tail characteristic. There are only 73 hashtags with an eigenvector centrality greater than 0.8 and 28 hashtags with an eigenvector centrality greater than 0.9. On the other hand, most hashtags fall into the category with an eigenvector centrality between 0 and 0.2 , which is a strong indication of the standard behaviour in social networks regarding hashtag usage (Kordumova et al., 2016) see Table 1 and Figure 2.

Based on the degree centrality and eigenvector centrality values, 5 main areas can be identified that are connected with organic food on Instagram: \#healthyfood, \#vegan, \#healthy, \#eatclean, \#vegetarian. All these areas are closely related to the area of "healthy" In addition to the \#healthyfood and \#healthy hashtags, there are also \#vegan and \#vegetarian. Vegans were significantly more likely to consider themselves "healthy" (Heiss et al., 2017). Focusing on the practical implication of this study, the organic food can very much appeal to the segments of "vegans" and "vegetarians".

Table 2 presents the results of the literature review based on the 14 papers selected. The table contains the author(s) of the study, the aim of research, sample size and identified factors.
According to the aim of this paper, these were factors influencing consumers' attitude to organic food, factors affecting purchase intention and consumer motivation to buy organic food.

The factors identified in the studies can be divided into 7 groups: (1) health consciousness, (2) ecological motives, (3) tasty, (4) knowledge and attitude, (5) price, and (6) hedonism. Factors from all the groups - with the exception of price - support positive attitude and purchase intention of consumers. In this case, price can be seen as a barrier to the development of the organic food market (Bryla, 2016). Significantly represented are also the factors health, ecological motives, tasty, and knowledge and attitude. The "healthy" factor was identified in all the studies, "ecological motives" were identified in 7 studies, "tasty" in 5 studies and "knowledge and attitude" in 4 studies.

Even though the effect of organic food on human health hasn't been sufficiently proved (e.g. Popa et al., 2018), the results of the questionnaire surveys and of the social network analysis show that for consumers, the "healthy" aspect is the prominent motivation to buy organic food. The \#healthy and \#healthyfood hashtags are among the most frequently identified hashtags with the highest value of eigenvector centrality, and the "healthy" factor was identified as significant in all the studies (see Table 3). This is in agreement with the "health consciousness" area identified in the questionnaire surveys (see Table 2).

\section{Eigenvector Centrality Distribution}

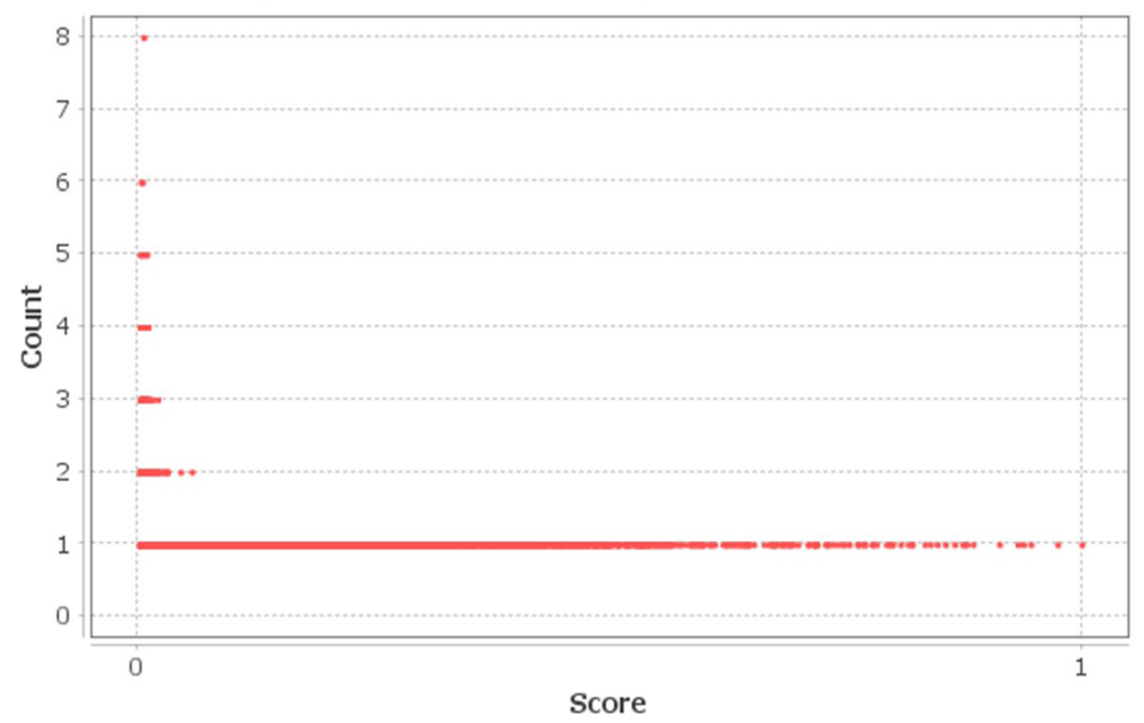

Source: own processing

Figure 2: Eigenvector centrality distribution of hashtags connected to hashtag \#organicfood. 


\begin{tabular}{|c|c|c|c|}
\hline Citation (Authors) & Aim of research & Sample size & Identified factors \\
\hline $\begin{array}{l}\text { Asif, Xuhui, Nasiri } \\
\text { and Ayyub (2018) }\end{array}$ & $\begin{array}{l}\text { "Understanding the factors that affect the purchase } \\
\text { intention of organic food. }\end{array}$ & 736 & $\begin{array}{l}\text { "attitude } \\
\text { health consciousness }\end{array}$ \\
\hline $\begin{array}{l}\text { Hansen, Sørensen } \\
\text { and Eriksen (2018) }\end{array}$ & $\begin{array}{l}\text { To develop model, which specifies expected } \\
\text { relationships between consumer motivations, organic } \\
\text { food identity, and organic food behaviour. }\end{array}$ & 1.176 & health consciousness \\
\hline $\begin{array}{l}\text { Singh and Verma } \\
(2018)\end{array}$ & $\begin{array}{l}\text { To examine the factors influencing the consumers' } \\
\text { actual buying behaviour towards organic foods }\end{array}$ & 611 & $\begin{array}{l}\text { health consciousness } \\
\text { knowledge } \\
\text { subjective norms price }\end{array}$ \\
\hline Chekima et al. (2017) & $\begin{array}{l}\text { To propose a new approach to determine factors } \\
\text { influencing organic food consumption. }\end{array}$ & 133 & $\begin{array}{l}\text { "Product-specific attitude } \\
\text { health orientation sensory appeal }\end{array}$ \\
\hline Bryla (2016) & To select aspects of organic food consumption. & 1 & $\begin{array}{l}\text { more expensive } \\
\text { healthier } \\
\text { more environmentally friendly } \\
\text { tasty }\end{array}$ \\
\hline Teng and Lu (2016) & $\begin{array}{l}\text { "To examine the effect of consumption motives } \\
\text { onbehavioural intention related to organic food } \\
\text { consumption. }\end{array}$ & 457 & $\begin{array}{l}\text { health } \\
\text { consciousness } \\
\text { ecological motives }\end{array}$ \\
\hline $\begin{array}{l}\text { Ueasangkomsate } \\
\text { and Santiteerakul } \\
(2016)\end{array}$ & $\begin{array}{l}\text { To identify the consumers' } \\
\text { attitudes and intention to buy organic foods. }\end{array}$ & 316 & health \\
\hline Basha et al. (2015) & $\begin{array}{l}\text { To identify the purchase intention of consumers towards } \\
\text { organic foods }\end{array}$ & 50 & $\begin{array}{l}\text { quality of products } \\
\text { environmental concern } \\
\text { health concern and lifestyle }\end{array}$ \\
\hline Irianto $(2015)$ & $\begin{array}{l}\text { To study the variables affecting the consumer attitude } \\
\text { to buy organic food. }\end{array}$ & 200 & $\begin{array}{l}\text { health } \\
\text { environment }\end{array}$ \\
\hline $\begin{array}{l}\text { Yadav and Pathak } \\
(2016)\end{array}$ & $\begin{array}{l}\text { To understand the consumer's intention to purchase } \\
\text { organic food. }\end{array}$ & 220 & positive impact on their health \\
\hline $\begin{array}{l}\text { Mohamad, Rusdi } \\
\text { and Hashim (2014) }\end{array}$ & $\begin{array}{l}\text { "To investigate Malaysian consumers' awareness and } \\
\text { purchase intention towards organic food consumption." }\end{array}$ & 100 & good for health \\
\hline $\begin{array}{l}\text { Bauer, Heinrich } \\
\text { and Schäfer (2013) }\end{array}$ & $\begin{array}{l}\text { To verify four main purchasing motives for organic } \\
\text { food in Germany. }\end{array}$ & 630 & $\begin{array}{l}\text { healthiness } \\
\text { hedonism, environmental friendliness } \\
\text { food safety }\end{array}$ \\
\hline Zagata (2012) & $\begin{array}{l}\text { To explain the behaviour of organic food consumers } \\
\text { in the Czech Republic. }\end{array}$ & 1.054 & $\begin{array}{l}\text { positive health effects, } \\
\text { environmentally friendly production } \\
\text { better taste of organic food }\end{array}$ \\
\hline $\begin{array}{l}\text { Lea and Worsley } \\
(2005)\end{array}$ & To examine consumers' beliefs about organic food. & 500 & $\begin{array}{l}\text { healthier } \\
\text { tastier } \\
\text { better for the environment }\end{array}$ \\
\hline
\end{tabular}

Source: own processing

Table 2: Results of studies carried out using questionnaire surveys.

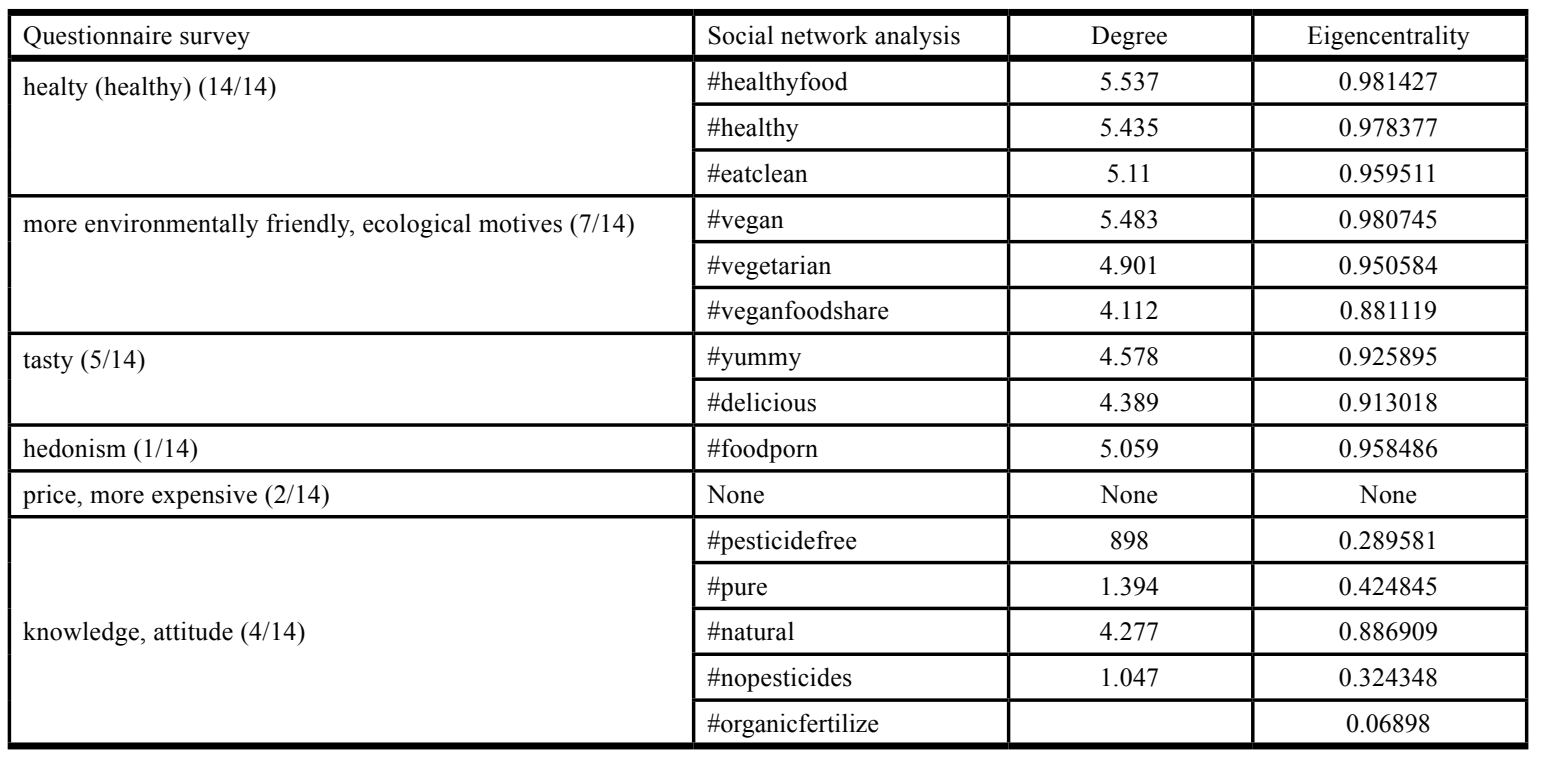

Source: own processing

Table 3: Hashtags corresponding to areas identified by a questionnaire survey at the organic food area. 
In the social network analysis, also the \#vegan and \#vegetarian hashtags had a high value of eigenvector centrality. Vegans and vegetarians can be defined as "persons who do not eat meat for health or religious reasons or because they want to avoid being cruel to animals" (Cambridge, 2018). As such, it involves not only the "healthy" motive, but also motives related to "environmentally friendly" and "ecological motives" (Stehfest, 2014). These hashtags can be included both in 1) health consciousness and 2) ecological motives and more environmentally friendly. The third area identified in the literature review is 3) tasty. In 5 studies, consumers claimed organic food was tastier. This opinion can be found in the social network analysis as well in relation to hashtags \#yummy and \#delicious. The fourth area is knowledge and attitude. The consumers' knowledge on organic food cannot be confirmed based on a specific hashtag directly related to "knowledge". Singh and Verma (2017) claim that consumers have inconsistent knowledge on what is "organic". That's why in their research on customer knowledge about organic food, they assess consumers' knowledge about the following characteristics: free from pesticides and chemical fertilizers, and are pure, natural and healthy (Singh and Verma, 2017). In the social network analysis, these areas can be found in the following hashtags: \#pesticidefree, \#pure, \#natural, \#nopesticides, \#organicfertilize. Based on the degree and eigenvector centrality values (see Table 3), only the \#natural hashtag can be identified as significant.

Among the five factors examined, "price" has a specific position being the only one that can be seen as a barrier to the development of the organic food market (Basha et al., 2015), with the other factors supporting the market development. In spite of that, there are many consumers for whom the higher price range of organic food is acceptable (Bryla, 2016). These are mostly more educated consumers with higher income (Sign and Verma, 2018). Price is also the only factor not involved in the broader concept of the social network analysis. Its absence in the social network hashtags can be related to the consumers' reluctance to publish information provoking discussion on the amount of their income. The last area discussed is "hedonism", as confirmed by Berry (2016) who claims that food brings delight. He even states that $60 \%$ of the sample agreed that eating could be as pleasurable as sex. This is obvious from the \#foodporn hashtag, mainly used by young people posting pictures of food on social networks (Vaterlaus et al., 2015).

\section{Future research}

Analysing hashtags on social networks identified 5 out of the 6 groups described based on questionnaire surveys, and in reaction to that, it is desirable to carry out more case studies identifying the behaviour of customers. Another option would be an analysis on farmers markets (\#farmersmarket), on local food (\#localfood), on veganism and vegetarianism (\#vegan and \#vegetarian) or on opinions on genetically modified food (\#gmofood).

The only area not identified in both types of research was price. We can assume that its absence in the social network hashtags can be related to the consumers' reluctance to publish information provoking discussion on the amount of their income. This assumption needs to be confirmed or proven false in further studies.

\section{Conclusion}

The study shows that the "healthy" area is the most communicated one on Instagram in relation to organic food, which is in line with the results of an analysis on studies conducted using questionnaire surveys. The "healthy" area is most frequently communicated using hashtags such as \#healthy, \#healthyfood, \#vegan, \#vegetarian and \#cleaneating. It is a combination of two most prominent areas: 1) health consciousness and 2) ecological motives and more environmentally friendly. In analysing hashtags with an eigenvector centrality greater than 0.9 (28 hashtags), 4 other basic areas can be identified, which were also found in the 14 studies carried out using questionnaire surveys: (1) health consciousness, (2) ecological motives and more environmentally friendly, (3) tasty and (5) hedonism. As for knowledge attitudes, hashtags can be found in the given set, but with a lower degree and eigenvector centrality. The only area that couldn't be confirmed by the social network analysis was price, which is a significant factor when buying organic food. There is an assumption that this could be related to the consumers' reluctance to publish information provoking discussion on the amount of their income, which needs to be confirmed by further studies.

\section{Acknowledgements}

This research article was supported by IGA PEF CZU (CULS) 20171033 - Regionální značení jako konkurenční výhoda, Nr. 00001959. 
Corresponding authors:

Ing. Ladislav Pilař, MBA, Ph.D.

Department of Management, Faculty of Economics and Management

Czech University of Life Sciences Prague, Kamýcká 129, 16500 Praha - Suchdol, Czech Republic

Phone:+420224382024 E-mail: pillar@pef.czu.cz

\section{References}

[1] Antoniou, I. E. and Tsompa, T. (2008) "Statistical analysis of weighted networks", Discrete Dynamics in Nature and Society, Vol. 1, pp. 1-16. ISSN 10260226. DOI 10.1155/2008/375452.

[2] Asif, M., Xuhul, W., Nasiri. A. and Samia, A. (2018) "Determinant factors influencing organic food purchase intention and the moderating role of awareness: A comparative analysis", Food Quality and Preference, Vol. 63, pp. 144-150. ISSN 09503293. DOI 10.1016/j.foodqual.2017.08.006.

[3] Aslam, S. (2018) "Instagram by the Numbers: Stats, Demographics \& Fun Facts. [Online]. Available: https://www.omnicoreagency.com/instagram-statistics. [Accessed: 18 April, 2018].

[4] Basha, M. B., Mason, C., Shamsudin, M. F., Hussain, H. I. and Salem, M. A. (2015) "Consumers Attitude Towards Organic Food", Procedia Economics and Finance, Vol. 31, pp. 444-452. ISSN 22125671. DOI 10.1016/S2212-5671(15)01219-8.

[5] Bauer, H. H., Heinrich, D. and Schäfer, D. B. (2013) "The effects of organic labels on global, local, and private brands. More hype than substance?"“, Journal of Business Research, Vol. 66, No. 8, pp. 1035-1043. ISSN 01482963. DOI 10.1016/j.jbusres.2011.12.028.

[6] Brennan, C., Gallagher, K. and McEachern, M. (2003) "A review of the 'consumer interest' in organic meat", International Journal of Consumer Studies, Vol. 27, No. 5, pp. 381-394. ISSN 1470-6423. DOI 10.1046/j.1470-6431.2003.00307.x.

[7] Brožová, I. and Beranová, M. (2017) “A Comparative Analysis of Organic and Conventional Farming Profitability“, AGRIS on-line Papers in Economics and Informatics, Vol. 9, No. 1, pp. 3-15. ISSN 1804-1930. DOI 10.7160/aol.2017.090101.

[8] Bryla, P. (2016) "Organic food consumption in Poland: Motives and barriers", Appetite, Vol. 105, pp. 737-746. ISSN 10958304. DOI 10.1016/j.appet.2016.07.012.

[9] Cambridge Dictionary (2018) "vegetarian“, Cambridge Dictionary. [Online]. Available: http://www.organic-word.net/yearbook/yearbook-2017.html [Accessed: 20 April, 2018].

[10] Gruzd A. (2016) "Netlytic: Software for Automated Text and Social Network Analysis", [Online]. Available: http://netlytic.org. [Accessed: 15 April, 2018].

[11] Hansen, T., Sørensen, M. I. and Eriksen, M. L. R. (2018) "How the interplay between consumer motivations and values influences organic food identity and behavior", Food Policy, 74, pp. 39-52. ISSN 03069192. DOI 10.1016/j.foodpol.2017.11.003.

[12] Hasimu, H., Marchesini, S. and Canavari, M. (2017) "A concept mapping study on organic food consumers in Shanghai, China“, Appetite, Vol. 108, pp. 191-202. ISSN 10958304. DOI 10.1016/j.appet.2016.09.019.

[13] Heiss, S., Coffino, J. A. and Hormes, J. M. (2017) "Eating and health behaviors in vegans compared to omnivores: Dispelling common myths", Appetite, Vol. 118, pp. 129-135. ISSN 10958304. DOI 10.1016/j.appet.2017.08.001.

[14] Huber, M., Rembialkowska, E., Średnicka, D., Bügel, S. and Van De Vijver, L. P. L. (2011) "Organic food and impact on human health: Assessing the status quo and prospects of research", NJAS - Wageningen Journal of Life Sciences, pp. 103-109. ISSN 15735214. DOI 10.1016/j.njas.2011.01.004.

[15] Chekima, B., Oswald, A, Walfa, S. A. W. S. K. and Chekima, K. (2017) "Narrowing the gap: Factors driving organic food consumption“, Journal of Cleaner Production, Vol. 166, pp. 1438-1447. ISSN 09596526. DOI 10.1016/j.jclepro.2017.08.086. 
[16] Irianto, H. (2015) “Consumers' Attitude and Intention towards Organic Food Purchase: An Extension of Theory of Planned Behavior in Gender Perspective“, International Journal of Management Economics and Social Sciences, Vol. 4, No. 1, pp. 17-31.[Online]. Available: http://www.ijmess. com. [Accessed: 20 April, 2018]. ISSN 2304-1366.

[17] Lea, E. and Worsley, A. (2007) “Australian consumers' food-related environmental beliefs and behaviours", Appetite, Vol. 50, No. 2-3, pp. 207-214. ISSN 01956663. DOI 10.1016/j.appet.2005.07.012.

[18] Malthouse, E. C., Haenlein, M., Skiera, B., Wege, B. and Zhang, M. (2013) "Managing customer relationships in the social media era: Introducing the social CRM house“, Journal of Interactive Marketing, Vol. 27, No. 4, pp. 270-280. ISSN 10949968. DOI 10.1016/j.intmar.2013.09.008.

[19] Mohamad, S. S., Rusdi, S. D. and Hashim, N. H. (2014) "Organic Food Consumption among Urban Consumers: Preliminary Results“, Procedia - Social and Behavioral Sciences, Vol. 130, pp. 509-514. ISSN 18770428. DOI 10.1016/j.sbspro.2014.04.059.

[20] Petticrew, M. and Roberts, H. (2008) "Systematic Reviews in the Social Sciences: A Practical Guide", 336 p. ISBN 9781405121101. DOI 10.1002/9780470754887.

[21] Pilař, L., Poláková, J., Gresham, G., Rojík, S. and Tichá, I. (2017) "Why People use Hashtags when Visiting Farmers' Markets", Agrarian Perspectives XXVI: Compettitiveness of European Agriculture and Food Sectors: Proceedings of the $26^{\text {th }}$ International Scientific Conference on Agrarian Perspectives, Prague, Czech Republic, pp. 287-292. ISBN 1804-1930X.

[22] Pilař, L., Balcarová, T., Rojík, S., Tichá, I. and Poláková, J. (2018) “Customer experience with farmers' markets: what hashtags can reveal", International Food and Agribusiness Management Review, Vol. 21, No. 6, pp. 755-770. ISSN 1559-2448. DOI 10.22434/IFAMR2017.0039.

[23] Popa, M. E., Mitelut, A. C., Popa, E. A., Stan, A and Popa, V. I. (2018) “Organic foods contribution to nutritional quality and value“, Trends in Food Science \& Technology, in press. ISSN 0924-2244. DOI 10.1016/J.TIFS.2018.01.003.

[24] Singh, A. and Verma, P. (2017) "Factors influencing Indian consumers' actual buying behaviour towards organic food products“, Journal of Cleaner Production, Vol. 167, pp. 473-483. ISSN 09596526. DOI 10.1016/j.jclepro.2017.08.106.

[25] Stehfest, E. (2014) "Diet: Food choices for health and planet", Nature, Vol. 515, pp. 501-502. ISSN 1476-4687. DOI 10.1038/nature13943.

[26] Statista (2017) "Number of worldwide social network users 2010-2021", Statistic. Statista. [Online]. Available: https://www.statista.com/statistics/278414/number-of-worldwide-social-network-users/ [Accessed 15 April, 2018].

[27] Teng, C. C. and Lu, C. H. (2016) "Organic food consumption in Taiwan: Motives, involvement, and purchase intention under the moderating role of uncertainty“, Appetite, Vol. 105, pp. 95-105. ISSN 10958304. DOI 10.1016/j.appet.2016.05.006.

[28] Ueasangkomsate, P. and Santiteerakul, S. (2016) “A Study of Consumers' Attitudes and Intention to Buy Organic Foods for Sustainability“, Procedia Environmental Sciences, Vol. 34, pp. 423-430. ISSN 18780296. DOI 10.1016/j.proenv.2016.04.037.

[29] Vaněk, J., Brožová, I., Masner, J., Šimek, P. and Vogeltanzová, T. (2013) "Information support of regions - organic farming“, Agris On-line Papers in Economics and Informatics, Vol. 5, No. 3, pp. 97-104. ISSN 18041930.

[30] Willer, H. and Kicher, R. (2016) "The world of organic agriculture. Statistics and emerging trends", Research Institute of Organic Agriculture FiBL and IFOAM Organics International. [Online]. Available: http://www.organic-word.net/yearbook/yearbook-2017.html. [Accessed 5 April, 2018]. ISSN 0014-4797. DOI 10.4324/9781849775991.

[31] Wilson, C. (2013) "Questionnaires and Surveys", in "Credible Checklists and Quality Questionnaires", Morgan Koufmann, pp. 29-79. ISSN 9780124103924. DOI 10.1016/B978-0-12-410392-4.00002-7. 
[32] Worthington, V. (2001) "Nutritional quality of organic versus conventional fruits, vegetables, and grains ", Journal of alternative and complementary medicine (New York, N.Y.), Vol. 7, No. 2, pp. 161-173. ISSN 1075-5535. DOI 10.1089/107555301750164244.

[33] Yadav, R. and Pathak, G. S. (2016) "Intention to purchase organic food among young consumers: Evidences from a developing nation“, Appetite, Vol. 96, pp. 122-128. ISSN 10958304. DOI 10.1016/j.appet.2015.09.017.

[34] Zagata, L. (2012) "Consumers' beliefs and behavioural intentions towards organic food. Evidence from the Czech Republic", Appetite, Vol. 59, No. 1, pp. 81-89. ISSN 01956663. DOI 10.1016/j.appet.2012.03.023. 